Digital Press Social Sciences and Humanities

Contextualization of Pancasila in The Regional's Policy to Overcome the Covid-19 in Bali

Kusuma Putri and I Putu Adi Permana Putra

Proceeding of 9th International Conference on Nusantara Philosophy (ICNP) Arndt Graf, Fitri Alfariz, M Rodinal Khair Khasri, Rachmad Hidayat, Rokhmat Sairah, Zaid bin Ahmad (eds) 


\title{
Contextualization of Pancasila in The Regional's Policy to Overcome the Covid-19 in Bali
}

\author{
Kusuma Putri ${ }^{*}$, I Putu Adi Permana Putra ${ }^{2}$ \\ 1 Laboratory of Nusantara Philosophy, Universitas Gadjah Mada, Yogyakarta, Indonesia \\ 2 Master of Public Administration, Postgraduate Program, Universitas Warmadewa, Denpasar, Indonesia \\ *e-mail : kusuma.putri@mail.ugm.ac.id
}

\begin{abstract}
Since the presence of the Covid-19 pandemic, various policies have been issued by the central government and regional governments to provide a response to the community in order to maintain safety and good social security for the community. The form of regional policies as a form of regional government response in dealing with the Covid-19 pandemic is in accordance with the social dynamics that occur in the community. The existence of regional policy will certainly be adaptive and efficient in dealing with Covid-19 in the regions. Conformity is one of the important considerations in determining various policies. Therefore, this research will focus on the selected regional policy as a strategy to accelerate the response to the impact of the Covid-19 pandemic in Bali Province. The method in this research uses a qualitative approach with descriptive analysis techniques, that means there is a description that will discuss related themes through primary data obtained from literature studies in strengthening the research. The results in this research are a form of contextualization of Pancasila in regional policy as an effort to overcome Covid-19 in Bali Province. The values of regional wisdom that grow in Balinese society have relevance to the values of Pancasila which make Pancasila a guiding principle for the community. This also facilitates Balinese regional geniuses to continue exist in every line of people's lives, one of which is through regional policy. This kind of melodic policy making trains regions to act quickly and efficiently in responding to the needs of their communities. The Traditional Village-based Mutual Cooperation Task Force is a form of regional policy in Bali Province. Through the Covid 19 Task Force, social cohesion forms in the community and becomes a means for the implementation of Pancasila values. Contextualization of Pancasila values becomes the dissemination spaces for every element of community and institutions to always embody the noble values of Pancasila in the life of the nation, state and community both during the pandemic and post-pandemic.
\end{abstract}

\section{Keywords}

Pancasila, Regional's Policy, Covid-19 Pandemic

\section{Introduction}

The corona virus outbreak (covid-19) has become a global disaster that has been faced by various countries around the world, including Indonesia. The emergence of the corona virus threatens human health and has an impact on the line of life. So many sectors have been affected by this virus, such as the recession faced by the economic sector, the education process through an online system, hampered socio-cultural activities, tourism activities have become paralyzed, and the life structure of the community has changed very significantly. Another thing that has been affected by this virus is that the social life of the community, lives and human civilization are threatened. It's a concern and urgency problem that must be resolved.

When various lines of life are affected by the Covid-19 pandemic, it requires state officials to immediately take appropriate action to suppress the spread of the corona virus which is troubling the public. Therefore, this domain has become a public domain and requires policy products that are able to provide guidance for the government order in responding to the increasing number of cases. Policy becomes a public product that is used as a media for reconciling public issues in order to ensure a sense of security in the community. Indonesia as one of the affected countries has made optimal efforts to fight against the invisible virus. Seeing the portrait of the development of cases that continue to increase, the 
government issued a policy as a seriousness of the country in dealing with the COVID-19 outbreak. The policies that have been issued include: Government Regulation Number 21 of 2020 concerning Large-Scale Social Restrictions in the Context of Accelerating Handling of Corona Virus Disease (Covid-19); Presidential Decree Number 11 of 2020 concerning the Determination of a Public Health Emergency of Corona Virus Disease (Covid-19); Executive order of the Republic of Indonesia Number 4 of 2020 concerning Refocusing Activities, Budget Reallocation, and Procurement of Goods and Services in the Context of Accelerating Handling of Corona Virus Disease (Covid-19).

All of the aforementioned policies were attempts and as an effort to deal with the COVID-19 pandemic. Based on data accessed on Kompas.com during the implementation of the Large-Scale Social Restriction Policy (PSBB) for the first period, the daily trend of positive cases of COVID-19 continued to increase. It has been recorded that since April 10, 2020 there have been 1,810 cases, increasing day by day until April 23, 2020 there were 3,506 cases. This is a strong reason for the central government to extend social restrictions and does not rule out the fact on the ground that increasing case development as of 27 July 2020, the total cases have reached 19,474 cases in Indonesia. This fact is quite serious and must be addressed immediately. Strategies and efforts are needed to break the chain of the spread of the Corona virus in Indonesia. Therefore, the synergy and systematic collaboration from the central government with regional governments is the most appropriate step to accelerate the handling of the impacts caused by Covid-9 so that the expansion of the benefits of the policies made will easily embrace the community as a form of state presence in critical period like this.

Various policies that have been rolled out by the central government in dealing with the Covid-19 pandemic will certainly not have positive implications if there is no good synergy between the central government and regional governments. Therefore, Indonesia needs to improve its strategy and optimize the Indonesian government system through regional policy (regional autonomy). The authority of the regional government is the key in dealing with the Covid-19 pandemic in each region. Therefore, the regional government has the opportunity to regulate its territory to deal with Covid-19 and integrate it with central policies. Through the authority possessed by the regional government, it demands an innovation and strategy to deal with this situation by moving systematically and fully prepared as an effort to prevent the spread of the corona virus in every region of Indonesia. One of the areas that has been in the spotlight and has been affected by the presence of this virus is the Province of Bali.

The province of Bali has felt a significant impact due to the pandemic that has paralyzed the economy of Bali through tourism activities. The Bali Provincial Government has made optimal efforts to overcome the Covid-19 case, but the number of cases is increasing. Based on daily data from March 2020 to April 27, 2020 the graph of positive cases in Bali has cumulatively reached 193 cases and it is possible that this number could continue to increase (JDIH Bali Province, 2020). Reflecting on the daily increase in COVID19 cases in Bali, it is a sign that serious handling is needed so as not to cause an expansion of the impact that threatens human health. A strategy has been chosen by the regional government of Bali which is to produce a joint decision in the form of a policy based on regional wisdom.

Joint Decree of the Governor of Bali and the Bendesa Agung of the Bali Province Traditional Village Council Number 472/660/PHA/DPMA and Number 003/SKB/MDA-Prov Bali/II/2021 concerning the establishment of a Mutual Cooperation Task Force (Satuan Tugas Gotong Royong) for Handling Covid-19 based on Traditional Village in Bali is a form of regional policy. The birth of this regional policy is an effort to stop the spread of the virus and increase positive cases of Covid-19. This policy is an updated policy from the previous Number 472/1571/PPDA and Number 05/SK/MDA-Prov Bali/III/2020 regarding the establishment of the Task Force for Cooperative Handling Covid-19 based on Traditional Village in the Province of Bali. The selection of Traditional Village is very appropriate because Traditional Village is an important locus of state tools and are the rational choice of the Governor of Bali in embracing and making Traditional Village as the spearhead in overcoming Covid-19(Suryawan, 2020). Traditional Village are also a manifestation of Balinese regional wisdom that has authority, both autonomous rights and obligations in managing its community. The presence of the Traditional Village-based Mutual Cooperation Task Force in Bali is a wise policy from the Regional Government in Bali because it provides a new alternative in suppressing the spread of the Covid-19 virus by adopting the values of regional wisdom that grows and develops in the community. Based on Detiknews, the Bali government has also shown its success in suppressing the rate of addition of positive cases of the corona virus through the value of regional wisdom in the form of mutual cooperation which then moved the formation of a task force at the Indigenous Village level This has become an interest in conducting an analysis of regional policy in Bali regarding the roles and values contained in them. How to successfully reduce the rate of addition of Covid-19 cases in Bali can be done.

The form of the regional policy of the Province of Bali by establishing a Mutual Cooperation Task Force (Satuan Tugas Gotong Royong) based on Traditional Village in Bali is a tangible manifestation of the 
implementation of top-down policies and full of axiological values for the lives of Balinese people in particular. This is because the regional policy seeks to optimize the noble values of the Balinese people to always live in good harmony, namely Tri Hita Karana. Live with full balance and quality of life in order to face all forms of challenges of the new era or era. Therefore, the philosophical basis of this policy is the expansion of the meaning of policies based on regional wisdom values that are in line with the Pancasila concept, considering that Pancasila is a manifestation of the values of the nation's wisdom that continues to be inherited and has been carried as a guiding value to date. Thus, the regional policy of the Bali Province which seeks to carry the values of this wisdom becomes a road map for regional policy that is Pancasilaist.

\section{Methods}

This research is a type of qualitative research using a descriptive analysis approach. The data collecting technique is used by conducting non-participatory observations, literature studies related to policies, journal articles, books as primary sources and other supportings data form internet as secondary data. The data that has been obtained will be inventoried and then analyzed critically. The data analysis technique used was descriptive qualitative analysis in order to describe the reality of the situation under study.

\section{Results and Discussion}

\subsection{Regional Policy: Concept and Implementation}

Policy is a planned and systematic action with clear objectives. This is in accordance with Anderson's (1994) view in (Solichin, 2016: 8) policy is a purposive course of action or inaction undertaken by an actor or set of actors in dealing with a problem or matter of concern. The point is that policy is a product of activity that is chosen by the government with the intention of solving public problems that occur in society. In essence, a public policy has a typology to be able to understand the content of the policy, policy goals and policy objectives. In this case, the policy discussed is regional policy, which means that it is a government product that serves as a guide for acting through regional wisdom.

Understanding regional policy means understanding a rule that is born from an area or region. This policy was chosen by the regional government by taking into account the socio-cultural conditions of the community and the values of regional wisdom. Through the presence of regional policy, this makes it easier for regional governments with the authority they have to manage their regions. Regional policy becomes the legal protection in regulating and solving problems faced by the community in an area. Regional policy can also be a guideline for people to act and behave in certain areas. It is believed that the appearance of regional policy will more effectively regulate people's lives and accelerate the resolution of public problems that are focused on an area.

The regional policy referred to in the research is the Policy for the Establishment of a Mutual Cooperation Task Force (Satgas) for Handling Covid-19 based on Traditional Village in Bali Province. This regulation focuses on dealing with the impacts that arise and breaking the chain of the spread of the corona virus in Bali Province. If observed and understood, this policy is a regional Balinese policy which is a type of crisis policy, according to Ripley (1985) in Kusumanegara (2010: 8) crisis policy is a policy made to overcome problems that arise suddenly or without any previous signs and are considered as a serious problem for a country. The formation of the Mutual Cooperation Task Force in Bali is an effort by the regional government of the Province of Bali to overcome the impacts caused by the 2019 coronavirus disease pandemic.

The regionality that appears in this policy is not only the locus of the area it regulates but also the content of the policy in which there is a value of regional wisdom, namely the Traditional Village. From a structural point of view, this policy is very strong in terms of community social cohesion because there is a synergy between actors in the traditional village and coordination at the sub-district, district/city and provincial levels. The establishment of the Traditional Village-Based Mutual Cooperation Task Force is a manifestation of the government's product in this era of regional autonomy. This policy is determined by a joint decision and signed by the Bendesa Adat or otherwise known as the head of village (Perbekel/Lurah). The Mutual Cooperation Task Force is only formed in Traditional Village whose jurisdiction is in the Urban Village area that implements the Implementation of Urban Village-based Emergency Public Activity Restriction (PPKM) based on the Covid-19 zone map that has been determined by the regional government, 
either the Regent or the Mayor. This regional policy is very interesting where in its implementation there is synergy between various elements in the Traditional Village that are involved including: Community security unit, Community Leaders, Religious Leaders, Traditional Leaders, Yowana Extension Officers, Health Workers, Youth Organizations, and Volunteers. This shows that the success of the strategy requires social ties and cooperation from community elements to be an effective key in preventing the spread of the Covid-19 virus (Suharyanti and Sutrisni, 2021). Clearly defined regional policy includes a bottom-up model that links two contexts or environments to organizational management and culture skills in implementation and freedom in policy application (Parsons, 2011: 470-471). The bottom-up model emphasizes the facts on the field. Based on the results of field observations, the implementation of the Mutual Cooperation Task Force policy clearly shows there is a control and communication system with resources (implementors) that can carry out the task of implementing policies. This is a fact of the relationship between policy makers and policy implementers for the flexibility in implementing policies. Policy integration, implementer synergy, Traditional Village involvement funds and their elements are the keys that regional policies through regional wisdom become effective in accelerating the handling of the COVID-19 pandemic in Bali Province, especially Denpasar City.

The implementation of this policy has important tasks which are grouped into two groups, namely Niskala and Sakala. The terms niskala and sakala are concepts of the life of the Hindu community in Bali known as 'Rwa Bhineda'. This concept consists of two different sides, so it is a dualistic concept that causes the world to be in harmony (Ardana, 2012). Understanding the concept of rwa bhineda means understanding the differences, the essence of differences and harmonization of differences, so that $r w a$ bhineda is a polarization of life about all forms of dualism, namely the real world or the visible realm that is sensed (sakala) and other realms or the invisible realm (niskala) (Sumarjo in Ardana(2012)). The details of the task are described as follows:

1. Niskala Tasks;

The form of the task carried out is to pray to Almighty God (Ida Bhatara Sasuhunan at Kahyangan Temple, Traditional Village) to ask for serenity, harmony, and security for Nature, Society, and Balinese Culture in the face of the COVID-19 pandemic;

2. Sakala Task;

This task is divided into several activities, namely: 1) Covid-19 Prevention Activities, by carrying out socialization and public education in preventing the spread of the virus by implementing a healthy and covid-19-free lifestyle, coaching and monitoring related to covid-19, supporting health workers to take the necessary actions in handling covid-19 at the Wewidangan Traditional Village/Village Region/Urban Village; 2) Building Mutual Cooperation among the Traditional Village communities in collecting data on the needs of the affected communities, collecting assistance from capable communities and distributing them to affected communities in the related Traditional Village areas in order to ease the burden of living due to Covid-19.

The elaboration of the Covid-19 Gotong Royong Task Force policy illustrates that this regional policy in the Bali Province is included in the form of regional autonomy. There is regional authority in regulating the community to face the Covid-19 pandemic through their own strategies. Traditional Village, through this regional policy, have the authority to regulate Traditional Village Krama, as a form of optimizing Balinese regional wisdom in the midst of a pandemic. The description of the tasks carried out, in accordance with the contents of the policy, is a manifestation of the application of the axiological concept of life in Bali. The axiological dimension that is embedded in this regional policy leads to the value of life in the form of Tri Hita Karana (Three causes of happiness), namely: the relationship between man and God (parahyangan); human relations with humans (pawongan) and human relations with nature (palemahan) which must be maintained in order to achieve prosperity and harmony in this new era.

The values of regional Balinese wisdom contained in it make this regional policy Pancasilaist because philosophically this policy seeks to overcome Covid-19 through social beliefs that are present in the values of life (axiological dimensions) that thrive in Balinese society. This form of social trust built by the community and regional leaders is what leads to how this regional policy plays an important role as a means of gathering confidence that the Province of Bali is able to overcome Covid-19 through regional policy and cooperative communities because they already have a common vision in the form of values that are the foundation of the community.

The form of the application of axiological values in this regional policy is a commitment of the Balinese people to accept the values of Pancasila which are very relevant to the values of the regional wisdom of the community. According to Wiratmaja, Suacana \& Sudana (2021) Pancasila contains elements that are upheld by all levels of Balinese society, in which the values of Pancasila are seen as theirs and become their way of life. Tri Hita Karana, as part of the regional genius of the Balinese people, is still being practiced and has become a guide for people's lives. Thus, the concepts of niskala and sakala contained in this 
regional policy strengthen the evidence that the local wisdom of the Balinese people contain the values of Pancasila and are very relevant in overcoming the Covid-19 pandemic through regional policy.

\subsection{The Form of Pancasila Values in The Regional Policy}

Pancasila are the five principles which are the state ideology, thus the five principles can not be separated from each other because the correlation between five principles are very close, intertwined, and in series not stand alone (Hatta, et al : 1977). Therefore, the existence of every principle of Pancasila becomes an important aspect to regulate the life of the nation, state, and society.

By looking the involvement of Pancasila in every aspect of people's lives certainly facilitates the process of civilizing Pancasila as a national principle that has the implementation and actualization of good values for the Indonesian people. Pancasila as the national principles has also given influence to the social dynamics that occur in the community to always provide space as a form of manifestation of the values of Pancasila which are reflected through community behavior. Apart from being the national principles, Pancasila has become a way of life (weltanschauung) for the Indonesian people so that it has a central role in strengthening the noble values of the nation in living the life of the nation, state, and society through the guiding values of Pancasila in each of its principles. According to Soekarno (1964) Weltanschauung Therefore, Pancasila is present as an encouragement for the community to strengthen its role as the nation's view of life which is projected through the attitude of the community's life based on the values possessed by Pancasila as a manifestation of the Indonesian nation's personality values. According to Ishak (2016) Pancasila are the most important values in terms of what the process of being a nation, state, and society should be. Pancasila as the ideology of the state as well as the ideology of the nation, is not only the values that the Indonesian people aspire to in the future (das sollen), but also becomes the embodiment of collective values that are always explored through the spirit of the life of the Indonesian people, since collective life in the archipelago it is organized (das sein).

When Pancasila becomes the source and validity of the values of community, nation, and state life, then the existing Pancasila principles will condense to values for society and the state. The value that will be the starting point to become the standard of criteria and value validity is the value that is inherent with truth so that it can be accepted by all people. The values of Pancasila basically have basic elements and elements that are good, and strengthen the criteria standards and value validity (Hastangka \& Ma'ruf, 2021). Therefore, the values of Pancasila act as a guide for the community to always be in an inherent zone with goodness and truth as the highest achievement in implementing the values of Pancasila. The form of community readiness in welcoming the presence of Pancasila can be seen from the various responses made by the community as a form of validity to the values of Pancasila.

Seeing the community's response to the values of Pancasila in regional policy in the Province of Bali, it shows the extent to which the validity of Pancasila values in bringing people to always be inherent in goodness and truth. The form of value validity that occurs can also be seen in several activities carried out by the Traditional Village Mutual Cooperation Task Force (Covid-19 Task Force) in tackling the Covid-19 pandemic in accordance with the Pancasila points in each of its principles.

\subsubsection{Belief in The One and Only God.}

The divine value reflected in this regional policy is seen in the prayer activities or Nunas ica to Ida Bhatara Sasuhunan at Kahyangan Tiga Temple/Kahyangan Traditional Village in accordance with the Regional Traditional Village Dresta. This prayer activity was carried out to ask for serenity, harmony, natural security, and Balinese culture during the covid-19 pandemic. This form of prayer shows that divine value is very fundamental so that it directs people to always believe in the existence of God and involve God in every activity. This form of actualizing the values of Pancasila through the first principles is a shield for the community to always uphold the values of divinity in social dynamics. Thus, it can be seen the seriousness of the Mutual Cooperation Task Force to cultivate Pancasila values at the practical level. An example of actualizing the values of Pancasila in the first principles are the existence of goodness and there is a good reflection for people to always share the good things in the society, like give some supports and do praying together to remember God The Almighty as the first priority for asking help. The first principles as guiding principles to implement the other principles of Pancasila. In line with this, the regional policy gives full support to actualize the principles of Pancasila, particulary the first principles.

\subsubsection{A Just and Civilized Humanity}

The practice of the 2nd principles reflected in the regional policy of the Covid-19 Task Force include: 1) The Traditional Village-Based Covid-19 Task Force carries out socialization, education, prevention, 
handling, guidance and supervision activities related to Covid-19 in accordance with the Circular Letter of the Governor of Bali Number 03 of 2021 concerning the Enforcement of Restrictions on Urban Village Based Community Activities in New Era of Life Order in Bali Province; 2) Directing the Krama of Traditional Village/Urban Village to implement a healthy and Covid-19-free lifestyle with 6M: Wearing the correct standard mask, Washing hands, Keeping distance, Reducing travel, Boosting immunity, and Obeying the rules; 3) Support health workers in carrying out 3T (Tracing, Testing and Treatment) and other necessary actions in handling Covid-19 in Wewidangan Traditional Village/Urban Village. This form of practice of principles seeks to create a just and civilized attitude in accordance with the context required in a regional policy. Various kinds of activities related to this second principles make this regional policy a facilitator in the realization of the values of Pancasila, especially in the second principles related to just and civilized humanity. In line with this, the form of implementation of this regional policy has always guided the community to live and get used to being exposed to the values of Pancasila which are the guiding actors in overcoming the impact of the Covid-19 pandemic in Denpasar, Bali.

\subsubsection{Unity of Indonesia.}

The most prominent values of Pancasila in this regional policy are the values of togetherness, cooperation and mutual cooperation. The practice of Pancasila values in the 3rd principles is clearly visible when carrying out tasks. In its implementation there are synergies with various elements including: Community Security Unit, The mobilization of family welfare empowerment team (TP PKK), Integrated Healthcare Center, Dasa Wisma, Community Leaders, Religious Leaders, Traditional Leaders, Yowana, Extension Officers, Village Assistance, Health Workers, Youth Organizations, and Volunteers. The attitude of mutual cooperation is also evident through the coordination and communication between the Covid-19 Task Force at the sub-district, district/city, and provincial levels. This form of synergy has triggered a common understanding regarding the importance of an effort to accelerate the handling of Covid-19 in Denpasar City. The source of Pancasila values that live in society makes these strategic steps in order to strengthen a policy system that is more responsive and adaptive to the community. The form of the value of mutual cooperation which is the strongest element in the regional policy system has imbued the value of the third principle of Pancasila as a form of implementation. The attitude of mutual cooperation, which has always been a reference, has become a guiding value for the Mutual Cooperation Task Force to work based on the values of Pancasila. Therefore, by looking at the form of implementation of Pancasila values in regional policy, it has strengthened the role and function of Pancasila as a source of community life values in the life of the nation, state and society.

\subsubsection{Democracy, Led by the Wisdom of the Representatives of The People}

The practice of the 4th principles is also seen and carried out carefully. The formation of the Mutual Cooperation Task Force is inseparable from the organizational structure in carrying out its duties, including: 1) Trustees consist of Village Trustees (Babinsa), Bhayangkara Trustees of Community Security and Order (Bhabinkamtibmas) and/or other elements in the Traditional Villagers/Village; 2) The chairman is elected by deliberation and consensus from the Village Head/Lurah, Bendesa adat or other designations, or other elements/figures deemed capable; 3) The Deputy Chairperson, Secretary, Treasurer and Field Coordination are elected by deliberation and consensus from the Traditional Village Prajuru or Urban Village Officials or Traditional Village Krama/Villagers/Urban Village residents who have the ability. This form of elaborating the values of Pancasila through the fourth principles tries to show how important it is to form a structural organizational system by prioritizing aspects of deliberation and consensus, especially in determining the chairman of the task force or sub-section of the task force. This habituates the community to always work based on democratic values which will eventually lead the community to become a society that upholds democratic principles, so that no member feels heavy in accepting every decision made by community groups.

\subsubsection{Social Justice for All Indonesian People.}

Social justice is also reflected very strongly in the attitude and atmosphere of kinship and mutual cooperation in the Covid-19 Task Force. This can be seen in the activity of building mutual cooperation among the Krama of the Traditional Village/Villagers/Urban Village through various activities, namely: 1) To record the manners of Traditional Village/Villager/Urban Village who need assistance with basic needs; 2) Collecting assistance from people who are able to work together and distribute it to the customary Village Krama/Village/Village residents affected by COVID-19 to ease the burden of their lives; 3) Collecting donations/funds from the community voluntarily to help Krama Traditional Village/Urban Village/Village Residents who need it and to support the implementation of the operational tasks of the Mutual Cooperation Task Force. The funds used in the implementation of the Covid-19 Task Force come from 1) 
Village Funds and can be supported from other Village income sources through Regional Government Budget; 2) Kelurahan through Regency/Municipal Regional Government Budget ;3) Traditional Village through Traditional Village Regional Government Budget; 4) Other sources that are legitimate and not binding. The use of funds for financing the needs of activities is carried out in a transparent, accountable and free from corruption and in accordance with laws and regulations and accountability for the use of costs is adjusted to the source of funding. As a follow-up step, there are instructions to assign the Traditional Peoples Promotion Office and the Community Empowerment, Village, Population and Civil Registry Offices to immediately coordinate and carry out monitoring. This form of social justice is manifested in the accountability of the work system of the Covid 19 Task Force. In addition to accountability in managing a transparent system, there is a value of justice that is sought in the achievement of the Task Force to maintain integrity and professionalism in managing the Task Force's work system so that it is always on target for all people who need assistance and services from this Mutual Cooperation Task Force. Thus, all actions based on the value of justice always live and work in this Mutual Cooperation Task Force as a form of commitment from the process of actualizing the values of Pancasila as the noble value of this archipelago.

\subsection{Implementation of Pancasila Values in The Regional Policy}

Regional policy provide space for the value of the nation's regional wisdom to take part in taking a role. Through this regional policy, it will provide flexibility for regions to form policies that are in accordance with the needs to respond to the ongoing COVID-19 pandemic. The form of regional policy for the Province of Bali through the formation of the Covid-19 Task Force based on Traditional Village is one of the efforts to actualize the values of Pancasila in a policy.

Pancasila as the national principles provides stimuli or encouragement for the community to move and act in harmony with the values contained in Pancasila. This is emphasized by Hastangka (2021) when repositioning Pancasila as the national principles, this will also make Pancasila the state ideology in order to provide guidance and direction for the community, nation and state in attitude and action. Therefore, it has become a logical consequence if the values of Pancasila, which are the guidelines and guides for the community, are also present in regional policies. The form of policies issued is based on regional needs and based on the noble values of the nation. The mutual cooperation attitude becomes a real implementation of the civilizing of Pancasila values in a policy made by a regional leader. The policy based on the value of regional wisdom issued by the regional leadership is the executor of the form of ideas for solutions related to the problem of dealing with the Covid-19 pandemic.

The existence of Pancasila values that live and support the social life of the community as a guiding value. Therefore, the value that appears in this regional policy is the value of mutual cooperation which has always been the spirit for the Covid-19 Task Force in Bali Province. This mutual cooperation value illustrates that there are values that are accidentally embedded in each individual who is a member of the Covid-19 Task Force in traditional village. The value that has grown in this Covid-19 task force is the value of institutionalized mutual cooperation, the value of mutual cooperation is very important in fighting the pandemic because it takes strong belief and resilience in implementing values that can be understood differently from other parties. The form of the value of mutual cooperation which is the starting point of the synergistic and participatory attitude of the traditional village communities who are members of this task force, of course has its own strength in serving and carrying out the duties of the Governor regarding the handling of the Covid-19 pandemic.

The value of mutual cooperation in the Covid-19 task force unit in this traditional village is a conscious attitude taken to jointly dedicate themselves to the common interest. Therefore, mutual cooperation has become an attitude that is reflected in the civilizing of Pancasila in everyday life, so that it is easy to find in social phenomena that occur in Indonesian society. Mutual cooperation is projected through Pancasila which acts as an ethical foundation in carrying out the role of nation and state. It is undeniable that the attitude of gotong royong has become a cultural attitude of the Indonesian people as part of the value of the nation's regional wisdom to solve a problem together or collaboratively. The mutual cooperation attitude of the Covid-19 Task Force in traditional village in Bali is the result of a projection of the values of Pancasila which are present through the attitudes and behavior of the people who have always been a view of life. According to Kaelan (2013), the view of life serves as a frame of reference in order to organize one's personal life, as well as when interacting in society and the natural surroundings. Thus, Pancasila as this view of life has provided a frame of reference for the community to have behavior based on the noble values of the nation, and make these noble values always to continue to live and work in the community. 
Pancasila as a nation's identity will certainly be seen to what extent its validity or application in people's lives, because it is this enforcement that makes Pancasila values live and work in Indonesian society (Ali, 2009). The life and working of the values of Pancasila in the life of the Indonesian people certainly has positive implications for carrying out a noble attitude that is wise in dealing with all the dynamics of social life today, including facing the Covid-19 pandemic. The life and operation of Pancasila values in people's lives shows that the values of Pancasila are universally applicable. According to Putri and Putra (2021) Pancasila shows its role in various aspects of people's lives, both universal and particular roles, both of which provide space for Pancasila to always accompany the community. This emphasizes that Pancasila is able to position itself to guide the community in any scope.

The COVID-19 Task Force based on Traditional village in Bali shows that there are efforts to implement Pancasila values through the value of mutual cooperation which was built as the main step to equalize the perception that this pandemic can be overcome through social beliefs that are integrated in the mutual cooperation attitude. The value of mutual cooperation reflects Pancasila because through mutual cooperation it can bring people together to carry out a common vision, therefore mutual cooperation is one of the attitudes that reflects the cultural identity of Indonesian society. The value of mutual cooperation has imbued the values of Pancasila and is a form of its practice. Pancasila provides direction and terms of reference related to life guidelines that are collected and projected through the life attitudes of each individual Indonesian society. This life guide always makes Pancasila a life partner for the Indonesian people to always live in harmony with the noble values of the nation. In line with this, mutual cooperation is a derivative of the crystallization of the values of the nation's regional wisdom through Pancasila to live the life of the nation and state.

By looking at the form of regional policy through the task of the Covid-19 Task Force based on Traditional Village in Bali which adopts the value of regional wisdom of Tri Hita Karana, precisely through the concept of pawongan (human relations with humans), the value of mutual cooperation thrives into the idealism of the Task Force in carrying out their duties. The form of integrating the value of mutual cooperation attached to the Task Force is an inspirational step in reviving the values of Pancasila through the attitude of mutual cooperation to deal with the Covid-19 pandemic. Through regional policy, the formation of a Task Force based on Traditional Village has become a collaborative space for the community to gather themselves to do social good by imitating the noble values of Pancasila through mutual cooperation. The mutual cooperation attitude that was present in the Covid-19 Task Force based on Traditional Village in Bali was reflected in the actions of members of the Task Force who worked hand in hand to provide the best performance in suppressing the growth of the Covid-19 virus, distributing social assistance, providing emotional and spiritual strengthening, all of which have been integrated in two ways niskala and sekala task.

The life of the value of mutual cooperation in the Covid-19 Task Force based on Traditional village confirms that Pancasila as the crystallization of the nation's noble values has succeeded in transforming it through the value of mutual cooperation which is a social attitude in dedicating oneself to breaking the Covid-19 chain, as well as supporting government policies in suppressing the acceleration rate of the spread Covid-19 virus. Thus, regional policy is the actualization of Pancasila values that are present through the life attitudes of individuals and Indonesian people in living life processes, especially during the current pandemic.

\section{Conclusions}

This Traditional Village-based Mutual Cooperation Task Force in Bali is a form of thought from the contextualization of Pancasila values which still has relevance to the values of regional Balinese local wisdom. This regional policy is a method for regional government administrators to deal with the Covid19 pandemic quickly, effectively, and efficiently. This is because in a crisis situation like this, responsive and adaptive steps are needed to meet the needs of the community as a manifestation of the service principle. In addition, the value of regional wisdom as the basis for the values of this Task Force provides a more flexible space for Traditional Village in Bali to convey ideas and actions related to handling the Covid-19 pandemic. Therefore, this cultural tradition related to sekala and niskala is not found in any area. The value of regional wisdom from the Balinese people is what gives the community its own strength to be optimistic in dealing with the Covid-19 pandemic.

The contextualization of Pancasila values in regional policy is an effort to strengthen a common vision in fighting the Covid-19 virus and its impacts. Pancasila, which is the life guide and attitude guide for the community, is also present as a life partner who always provides answers to the problems faced in the life 
of the nation, state and society. The strengthening of the Tri Hita Karana concept of life contained in the regional policy has positive implications for maintaining harmony in life in the midst of the COVID-19 pandemic. Traditional Village is the spearhead of the spirit of building synergy to overcome the pandemic. The results of this study indicate that there is contextualization of Pancasila in the regional policy as an effort to overcome the Covid-19 pandemic. The value of the Balinese people, regional geniuses, namely Tri Hita Karana, is reflected in the sakala and niskala tasks carried out by the Mutual Cooperation Task Force as a form of the presence of the value of regional wisdom in regional government policies. This shows that regional genius is a means of embodiment of Pancasila values that is effectively applied by the region. Through regional wisdom, the values of Pancasila are realized as guiding principles and views of life for people before the pandemic, in the midst of a pandemic, and in the future post-pandemic era. Thus, it is highly trusted that through Pancasila the social cohesion of the community is united and strengthened in overcoming Covid-19 in Indonesia, especially in the province of Bali.

\section{Acknowledgments}

Kusuma Putri and Adi Permana express our gratitude and also deep thanks to Laboratory of Nusantara Philosophy Universitas Gadjah Mada and Magister of Public Administration Universitas Warmadewa. In addition, we would like to thank in particular the guidance, the patience, and support from Dr. Hastangka, M.Phil in completing this project.

\section{References}

Ali, Asad Said. (2009). Negara Pancasila: Jalan Kemaslahatan Berbangsa. Jakarta: LP3ES

Ardana, I. (2012). SEKALA NISKALA: Realitas Kehidupan Dalam Dimensi Rwa Bhineda. Dewa Ruci Jurnal Pengkajian dan Penciptaan Seni, (8)1, 139-156. https://doi.org/10.33153/dewaruci.v8i1.1097

Detiknews. (2020, 13 Mei). Ini Strategi Bali Berhasil Lawan Corona Virus tanpa PSBB. Retrieved May, 15, 2019 from the independent website : https://news.detik.com/berita/d-5012616/ini-strategi-bali-berhasillawan-corona-tanpa-psbb/2.

Hastangka, Hastangka. (2021). Ketahanan Ideologi (Pancasila) Di Masyarakat Pada Masa Pandemi Covid 19. Jurnal Kajian Lembaga Ketahanan Nasional Republik Indonesia, 9 (1), 471-490

Hastangka, Hastangka., \& M Ma'ruf. (2021). Metode Pancasila dalam Menangkal Radikalisme. Jurnal Kewarganegaraan, 18 (2), 115-129

Hatta, M., Djojoadisurjo, A.B., Maramis, A.A., Sunario, Sunario., Pringgodigdo, A.G. (1977). Uraian Pancasila. Jakarta: MUTIARA

Ishak, Otto Syamsuddin. (2016). Pancasila, Hak Asasi Manusia, dan Ketahanan Nasional.Jakarta: Perpustakaan Nasional Republik Indonesia

JDIH. (2020). Update Penanggulangan Covid-19 di Provinsi Bali. Retrieved, April, 27 from independent website : https://jdih.baliprov.go.id/berita/2020/update-penanggulangan-covid-19-di-provinsi bali-senin27-april-2020

Joint Decree of the Governor of Bali and the Bali Province Traditional Village Council Number: 472/1571/PPDA/DPMA and Number: 05/SK/MDA-Prov Bali/III/2020

Joint Decree of the Governor of Bali and the Bali Province Traditional Village Council Number: 472/660/PHA/DPMA and Number: 003/SKB/MDA-Prov Bali/II/2021

Kaelan, Kaelan. (2013). Negara Kabangsaan Pancasila: Kultural, Historis, Filosofis, Yuridis, dan Aktualisasinya. Yogyakarta: PARADIGMA 
Kompas.(2020). Membandingkan Tren Penambahan Kasus Positif Covid-19 Sejak PSBB Transisi. Retrieved, July, 28, from independent website:

https://megapolitan.kompas.com/read/2020/07/28/15185491/membandingkan-tren-penambahan-kasuspositif-covid-19-sejak-psbb-hingga?page=all

Kusumanegara, S. (2010). Model dan Aktor dalam Proses Kebijakan Publik. Yogyakarta: Gave Media.

Parsons, Wayne. (2011). Public Policy: Pengantar Teori \& Praktik Analisis Kebijakan. Jakarta: Kencana Prenada Media Group.

Putri, Kusuma., \& Putra, I. P.A.P. (2021). Eksplorasi Nilai-Nilai Pancasila Dalam Permainan Tradisional GalaGala Sebagai Penguatan Karakter Generasi Muda. Jurnal Universitas Sebelas Maret. Social Humanities and Educational Studies(SHEs) Conference Series 4 (4), 120

Suharyanti, Ni Putu Noni., \& Sutrisni, Ni Komang. (2020). Strategi Pencegahan Penyebaran Virus Covid-19 Berbasis Adat di Bali. Prosiding Webinar Nasional Universitas Mahasaraswati Denpasar, 210-218. Social Humanities and Educational Studies (SHEs) Conference Series 4(4), 120

Suryawan, I. (2020). Desa Mawacara, Negara Mawatata: Bali's Customory Village Based State Policies in the Time of the Covid-19 Pandemic. Jurnal Politik, 6(1), 39-66.

The Constitution of the Republic of Indonesia Article 18b paragraph 2

Wahab, H. Solichin Abdul. (2016). Analisis Kebijakan: Dari Formulasi ke Penyusunan Model-Model Implementasi Kebijakan Publik. Jakarta: PT Bumi Aksara.

Wiratmaja, I., Suacana, I. W.G., \& Sudana, I.W. (2021). Penggalian Nilai-Nilai Pancasila Berbasis Kearifan Lokal Bali Dalam Rangka Penguatan Wawasan Kebangsaan. POLITICO: Jurnal Politik dan Pemerintahan, $1(1) ., 43-52$ 